\title{
Synthesis and Antimicrobial Activity of some 1,4-Disubstituted 1,2,3-Triazoles
}

\author{
Belkheira Mokhtaria $^{(1,2)}$ and El Abed Douniazad ${ }^{(1)}$ \\ ${ }^{(1)}$ Laboratory of Fine Chemistry (LCF), Department of Chemistry, Faculty of Exact and Applied Sciences, Oran- \\ 1 Ahmed Ben Bella University P.O. Box 1524 El Menaouer, 31100 Oran, Algeria. \\ ${ }^{(2)}$ Bechar-Tahri Mohamed University, P.O. Box 417 Bechar 08000, Algeria.
}

\begin{abstract}
We realized the highly selective synthesis of 1,4-disubstituted 1,2,3-triazoles starting from a terminal alkyne and arylazides, without the presence of metal catalyst, using the sequence hydroamination/1,3-dipolar cycloaddition reaction. The structure of synthesized products was determined by the usual spectroscopic methods (IR, ${ }^{1} H$ NMR and $\left.{ }^{13} \mathrm{C} N M R\right)$. The 1,2,3-triazoles obtained were tested for their antimicrobial properties. Most of them showed a significant antibacterial activity against Pseudomonas aeruginosa, Citrobacter freundii, Escherichia coli, Staphylococcus aureus, and a fungicidal activity against Aspergillus flavus and Aspergillus ochraceus.
\end{abstract}

Keywords: alkyne, biological activity, 1,3-dipolar cycloaddition, hydroamination, 1,2,3-triazole.

\section{Introduction}

1,2,3-triazoles are aromatic heterocycles containing three nitrogen atoms in succession on the fivemembered ring, they have been widely studied and the large number of triazole which has been synthesized shows that they possess applications in various fields. Indeed, 1,2,3-triazoles exhibit a broad spectrum of biological activity. They have been used as anti-HIV, anticancer, antiseptic, anti-inflammatory, antibacterial, antifungal, herbicidal agent and others [1]. In addition, these heterocycles were used as fluorescent agent and corrosion inhibitor. They also play a very important role in absorbing $U V$-radiation [2].

Recently, two efficient and very selective methods of obtaining 1,4-disubstituted 1,2,3-triazoles have been developed, starting from terminal alkynes and organic azides by 1,3-dipolar cycloaddition employs catalytic copper or ruthenium [3] (scheme 1).

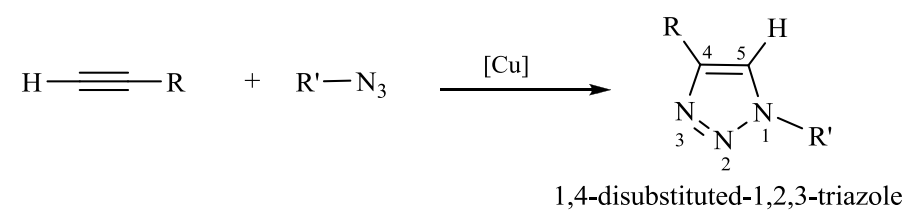

Scheme 1: Synthesis of 1,4-disubstituted 1,2,3-triazoles by copper-catalyzed alkyne-azide 1,3-dipolar cycloaddition

An alternative route of access to these heterocycles is the 1,3-dipolar cycloaddition between an enamine and an organic azide [4]. This process enables to synthesize 1,4-disubstitute1,2,3-triazoles in a highly regioselective manner and under ecological conditions; without the use of metal [5] (scheme 2).

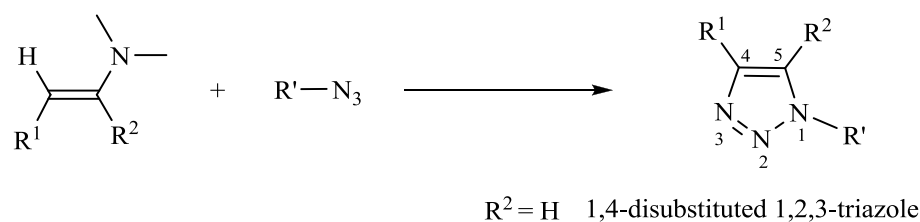

Scheme 2: Synthesis of 1,4-disubstituted 1,2,3-triazoles by enamine-azide 1,3-dipolar cycloaddition

Our study focuses on the synthesis of 1,4-disubstituted 1,2,3-triazoles from a terminal alkyne and avoiding the use of copper catalysis. The strategy adopted is to transform this acetylenic derivative by hydroamination reaction in enamine [6]. This intermediate can selectively add to the azide by 1,3-dipolar cycloaddition reaction to form 1,4-disubstituted-1,2,3-triazole (scheme 3). 


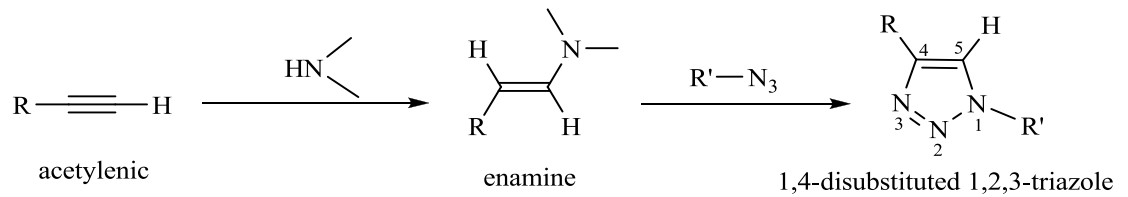

Scheme 3: Synthesis of 1,4-disubstituted 1,2,3-triazoles by hydroamination/1,3-dipolar cycloaddition reaction sequence

The objective is to valorize the 1,2,3-triazoles obtained by in vitro evaluation of their antimicrobial activity on the growth of some pathogenic microorganisms.

\section{II.1. Synthesis of enamine 1}

\section{Results And Discussion}

Addition of morpholine at room temperature to methyl propiolate in diethyl ether gives enamino-ester 1 [6a]. It is obtained in $88 \%$ yield and is characterized by a melting point of $75^{\circ} \mathrm{C}$ (scheme 4).

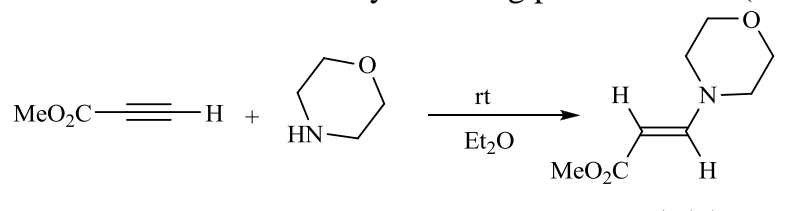

1 (E) $88 \%$

Scheme 4: Synthesis of enamine 1 from methyl propiolate and morpholine

\section{II.2. Synthesis of triazoles 3a-d}

The reaction between enamine $\mathbf{1}$ and arylazides 2a-d $[7,8,9]$ carried out without solvent by heating in a oil bath at $70^{\circ} \mathrm{C}$ leads to the triazoles 3a-d. The physical characteristics and yields of these heterocyclic are given in table I.

Table I: Yields and melting points of triazoles 3a-d

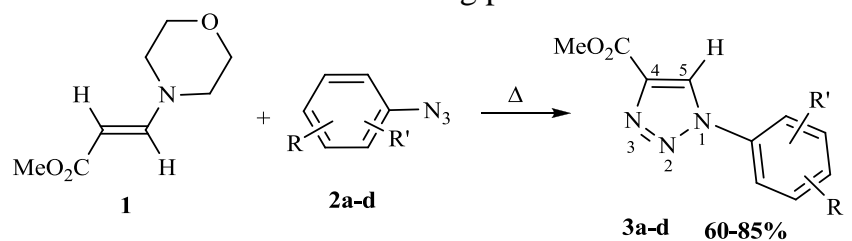

\begin{tabular}{|c|c|c|c|c|}
\hline Entry & Triazole & Aspect & Yield $\%^{\mathrm{a}}$ & $\mathrm{mp}\left({ }^{\circ} \mathrm{C}\right)$ \\
\hline 1 & & Yellow solid & 81 & 257 \\
\hline 2 & & White solid & 85 & 200 \\
\hline 3 & & Red-brick solid & 70 & 148 \\
\hline 4 & & Yellow solid & 60 & 76 \\
\hline
\end{tabular}

${ }^{a}$ isolated yields 
The enamino-ester $\mathbf{1}$ is added to arylazides $\mathbf{2 a - d}$ by 1,3-dipolar cycloaddition reaction giving 1,4disubstituted- $N$-aryl-1,2,3-triazoles 3a-d with good yields (table I) . The arylazides substituted by electronwithdrawing group (nitro) are the most reactive, they show the best results (yield $=81-85 \%$, table I, entry 1 and 2) compared to azide which carries an electron-donating substituent (methyl) within its structure (yield $=60 \%$, table I, entry 4).

Chloro-nitro-phenylazide gives the corresponding triazole in a yield of $70 \%$ (table I, entry 3 ). This addition reaction is regioselective, a single triazole is obtained. This selectivity is explained by the formation of a proximal triazoline in which the morpholino group is closest to aryl substituent of the azide (scheme 5).

Moreover, the hydrogen situated on the carbon $\mathrm{C}_{4}$ and in $\alpha$ position to the ester group is labile. The intermediate triazoline is unstable and removes a morpholine molecule to yield the corresponding triazole. This result is consistent with numerous works reported in the literature [9].
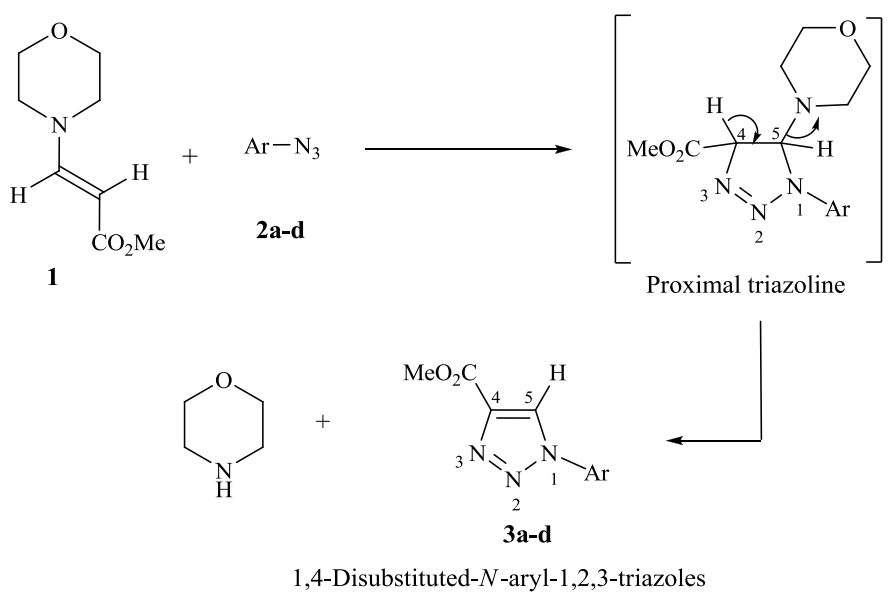

Scheme 5: Steps of triazole formation

\section{II.3. Biological evaluation of triazoles 3a-d}

In this study, we used four bacteria and two pathogenic fungi: Pseudomonas aeruginosa, Citrobacter freundii, Escherichia coli, Staphylococcus aureus, Aspergillus flavus and Aspergillus ochraceus. The bacterial strains of reference are taken from the Pasteur Institute of Algeria. While, both species of Aspergillus [11, 12]; moulds responsible for the contamination of wheat grain and coffee beans are isolated and identified in biological laboratory of Bechar university-Algeria [11c, 12a, d]. In vitro tests are carried out for determining the sensitivity of these microbial strains to synthesized triazoles compounds [10-13].

\section{II.3.1. Antibacterial effect}

The results of biological tests on the effect of triazoles 3a-d having concentrations of $1 ; 0.5 ; 0.25$; $0.125 \mathrm{mg} / \mathrm{mL}$ on the growth of four bacterial strains used in this study are summarized in tables II.

Table II: The inhibition zones diameters (D in $\mathrm{mm}$ ) of the growth of Staphylococcus aureus $(\mathrm{Sa})$, Pseudomonas aeruginosa $(P a)$, Escherichia coli $(E c)$ and Citrobacter freundii $(C f)$, registered for all concentrations of triazoles 3a-d.

\begin{tabular}{|c|c|c|c|c|c|c|c|c|c|c|c|c|c|c|c|c|}
\hline & \multicolumn{4}{|c|}{ 3a } & \multicolumn{4}{|c|}{ 3b } & \multicolumn{4}{|c|}{$3 c$} & \multicolumn{4}{|c|}{ 3d } \\
\hline & 1 & 0.5 & 0.25 & 0.125 & 1 & 0.5 & 0.25 & 0.125 & 1 & 0.5 & 0.25 & 0.125 & 1 & 0.5 & 0.25 & 0.125 \\
\hline$S a$ & $-^{\mathrm{a}}$ & - & - & - & - & - & - & - & 14 & - & 14 & - & - & - & - & - \\
\hline$P a$ & 9.5 & - & 13.5 & - & - & - & - & - & - & - & - & - & - & - & 7.5 & - \\
\hline$E c$ & - & - & - & - & - & - & - & - & 25 & 10 & - & - & 16 & - & - & - \\
\hline$C f$ & 10 & - & - & - & - & 8 & - & - & - & 7.5 & 7 & - & - & - & 7 & - \\
\hline
\end{tabular}

${ }^{a}$ no inhibition is detected.

To compare the antibacterial activity of triazoles $\mathbf{3 a - d}$ on each bacterium tested, we reported the results obtained in histograms (figure 1,2,3 and 4) permitting to represent the inhibition zones diameters of each bacteria growth depending on the different triazoles $\mathbf{3 a - d}$ concentrations used in this study. 


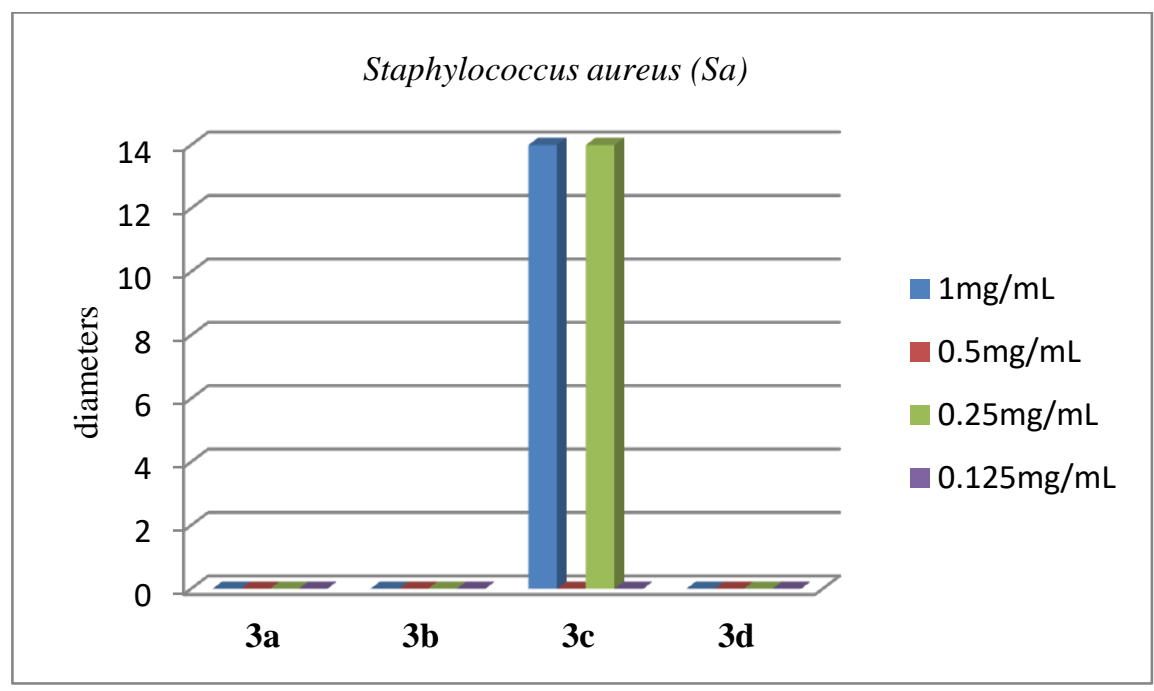

Figure 1: Single and potent triazole 3c inhibitor effect on Staphylococcus aureus ( $\mathrm{Sa}$ ) growth.

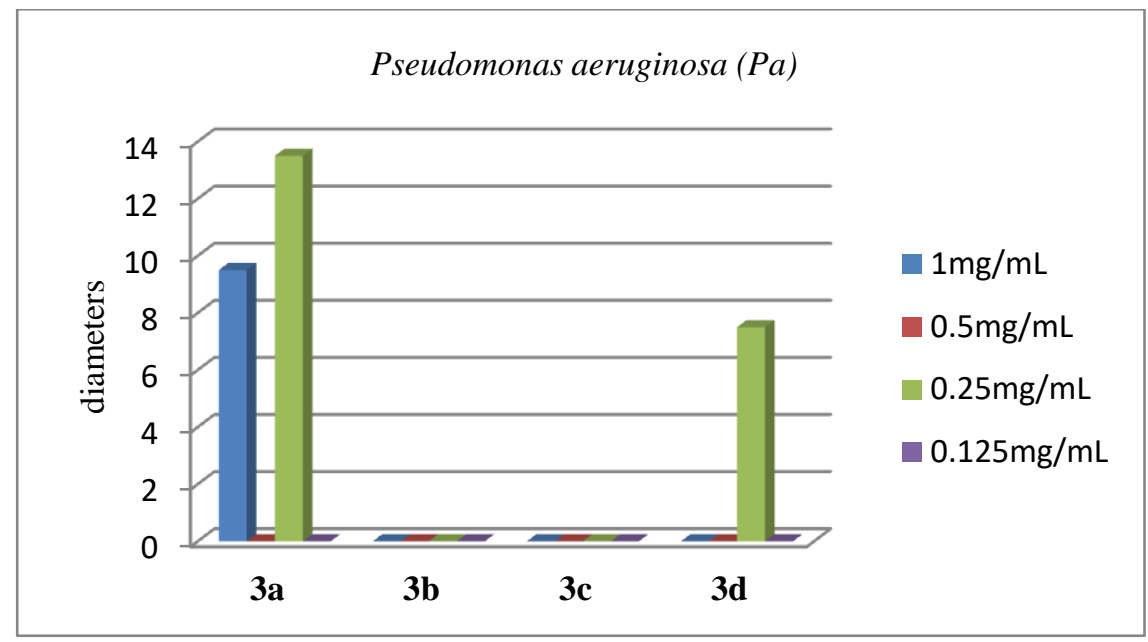

Figure 2: Pseudomonas aeruginosa $(\mathrm{Pa})$ is sensitive to triazoles $\mathbf{3 d}$ and $\mathbf{3 a}$, the latter is more effective on the growth inhibition of this bacterium $(\mathrm{D}=13.5 \mathrm{~mm}, M I C=0.25 \mathrm{mg} / \mathrm{mL})$.

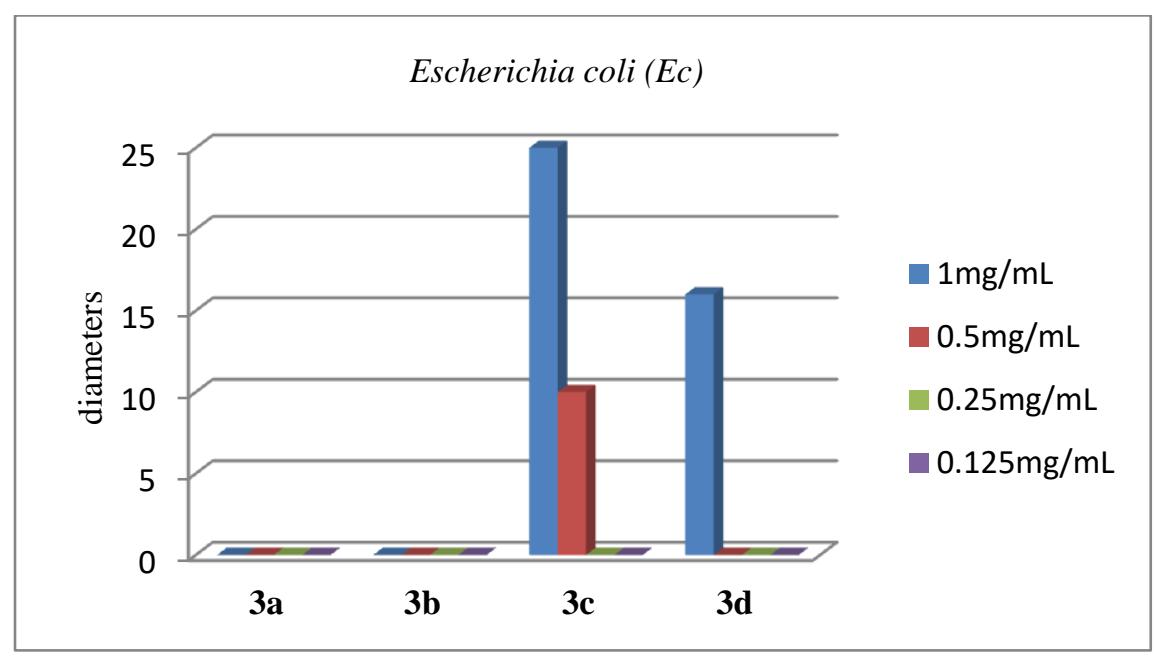

Figure 3: Significant inhibition areas are indicated by triazoles $\mathbf{3 c}$ and $\mathbf{3 d}$ against Escherichia coli $(E c)$. 


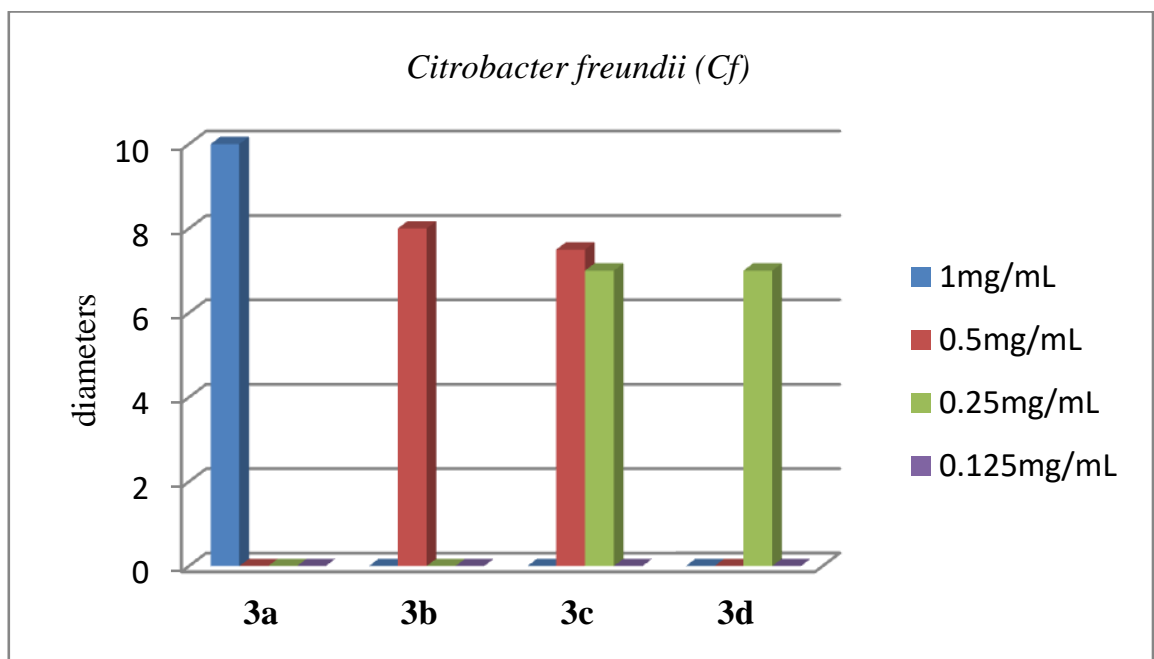

Figure 4: All triazole derivatives exert an inhibitory effect on Citrobacter freundii $(C f)$ growth.

The agar diffusion method [10] is employed to evaluate the antibacterial activity, using blotting paper disks which are impregnated by solutions with different concentrations of triazole 3a-d dissolved in DMSO and deposited on the bacterial strain surface. Inhibition areas of the bacterial growth was observed around the disks, the values of these diameters are measured (table II), they enable us to highlight the effect of different triazole concentrations on the bacteria used and search the small concentration beyond which no inhibition is observed (MIC). We notice antibacterial activity against two strains: Citrobacter freundii (Cf) and Pseudomonas aeruginosa $(\mathrm{Pa})$ recorded by the triazole 3a which possesses in its molecular structure the nitro group in para position on the benzene ring (table II).

The triazole 3b substituted by the nitro group in meta position exhibits an inhibitory effect only on the growth of Citrobacter freundii $(C f)$, with an inhibition diameter of $8.0 \mathrm{~mm}$ and a $M I C$ of $0.5 \mathrm{mg} / \mathrm{mL}$ (table II). Chloro-nitro-phenyltriazole 3c shows a bactericidal effect on Staphylococcus aureus (Sa), Escherichia coli (Ec) and Citrobacter freundii $(C f)$ (table II). It is more effective on Escherichia coli $(E c)(25.0-10.0 \mathrm{~mm})$ with a minimum inhibitory concentration $(M I C)$ of $0.5 \mathrm{mg} / \mathrm{mL}$. Triazole 3d, for its part, exerts a positive impact on Gram-negative bacteria: Pseudomonas aeruginosa $(\mathrm{Pa})$, Escherichia coli $(\mathrm{Ec})$ and Citrobacter freundii $(\mathrm{Cf})$. This triazole having a methyl substituent on phenyl revealed the appearance of inhibition zones around the disks containing them with diameters varying between 7.0 and $16.0 \mathrm{~mm}$ (table II).

Resistance of Staphylococcus aureus (Sa); Gram-positive bacterium is observed to against triazoles 3a, $\mathbf{3 b}$ and $\mathbf{3 d}$. However, only triazole $\mathbf{3 c}$ is active on this microorganism, showing a diameter and a $M I C$ in the range of $14 \mathrm{~mm}$ and $0.25 \mathrm{mg} / \mathrm{mL}$ respectively (table II, figure 1). It should be noted that Citrobacter freundii $(C f)$ is most sensitive to the triazole system because all triazoles have shown activity against this Gram-positive pathogenic bacterium, the inhibition zones diameters are between 7.0-8.0 $\mathrm{mm}$ (table II, figure 4).

\section{II.3.2. Fungicidal effect}

On the other hand, the tests results of the antifungal activity of triazoles 3a-d on the growth of two strains: Aspergillus flavus and Aspergillus ochraceus are summarized in tables III and IV respectively.

Table III: Zones diameters (I in $\mathrm{cm}$ ) of the Aspergillus flavus growth and the inhibition rates (T\%) obtained with different triazoles 3a-d concentrations: $1 ; 0.5 ; 0.25 ; 0.125 \mathrm{mg} / \mathrm{mL}$.

\begin{tabular}{cccccccccc}
\hline & \multicolumn{3}{c}{ 3a } & \multicolumn{3}{c}{ 3b } & \multicolumn{2}{c}{ 3c } & \multicolumn{3}{c}{ 3d } \\
\cline { 2 - 9 } & $\mathrm{I}(\mathrm{cm})$ & $\mathrm{T}(\%)$ & $\mathrm{I}(\mathrm{cm})$ & $\mathrm{T}(\%)$ & $\mathrm{I}(\mathrm{cm})$ & $\mathrm{T}(\%)$ & $\mathrm{I}(\mathrm{cm})$ & $\mathrm{T}(\%)$ \\
\hline 1 & 5.72 & 12.30 & 6.25 & 3.85 & 3.90 & 40.00 & 6.00 & 7.70 \\
0.5 & 5.60 & 13.85 & 6.40 & 1.54 & 6.10 & 6.15 & 6.30 & 3.10 \\
0.25 & 6.11 & 6,15 & 5.25 & 19.23 & 6.40 & 1.54 & 6.40 & 1.54 \\
0.125 & 6.00 & 7.70 & 6.40 & 1.54 & 6.30 & 3.10 & 6.25 & 3.85 \\
\hline
\end{tabular}

$\mathrm{I}_{0}$ : growth of Aspergillus flavus in absence of triazole, $\mathrm{I}_{0}=6.50 \mathrm{~cm}$. 
Table IV: Zones diameters (I in $\mathrm{cm}$ ) of the Aspergillus ochraceus growth and the inhibition rates (T\%) obtained with different triazoles 3a-d concentrations: $1 ; 0.5 ; 0.25 ; 0.125 \mathrm{mg} / \mathrm{mL}$.

\begin{tabular}{ccccccccc}
\hline & \multicolumn{3}{c}{ 3a } & \multicolumn{2}{c}{ 3b } & \multicolumn{3}{c}{ 3c } \\
\cline { 2 - 9 } & $\mathrm{I}(\mathrm{cm})$ & $\mathrm{T}(\%)$ & $\mathrm{I}(\mathrm{cm})$ & $\mathrm{T}(\%)$ & $\mathrm{I}(\mathrm{cm})$ & $\mathrm{T}(\%)$ & $\mathrm{I}(\mathrm{cm})$ & $\mathrm{T}(\%)$ \\
\hline 1 & 2.70 & 44.89 & 2.25 & 54.08 & 3.45 & 29.59 & 1.40 & 71.43 \\
0.5 & 3.20 & 34.69 & 3.30 & 32.65 & 1.30 & 73.47 & 1.35 & 72.45 \\
0.25 & 3.00 & 38.77 & 3.60 & 26.53 & 2.80 & 42.86 & 3.25 & 33.67 \\
0.125 & 3.20 & 34.69 & 2.65 & 45.92 & 3.05 & 37.76 & 3.25 & 33.67 \\
\hline
\end{tabular}

$\mathrm{I}_{0}$ : growth of Aspergillus ochraceus in absence of triazole, $\mathrm{I}_{0}=4.91 \mathrm{~cm}$.

The data given in tables III and IV are illustrated in histograms (figure 5 and 6), which express the inhibition rates of the fungal growth as a function of each concentration of triazoles.

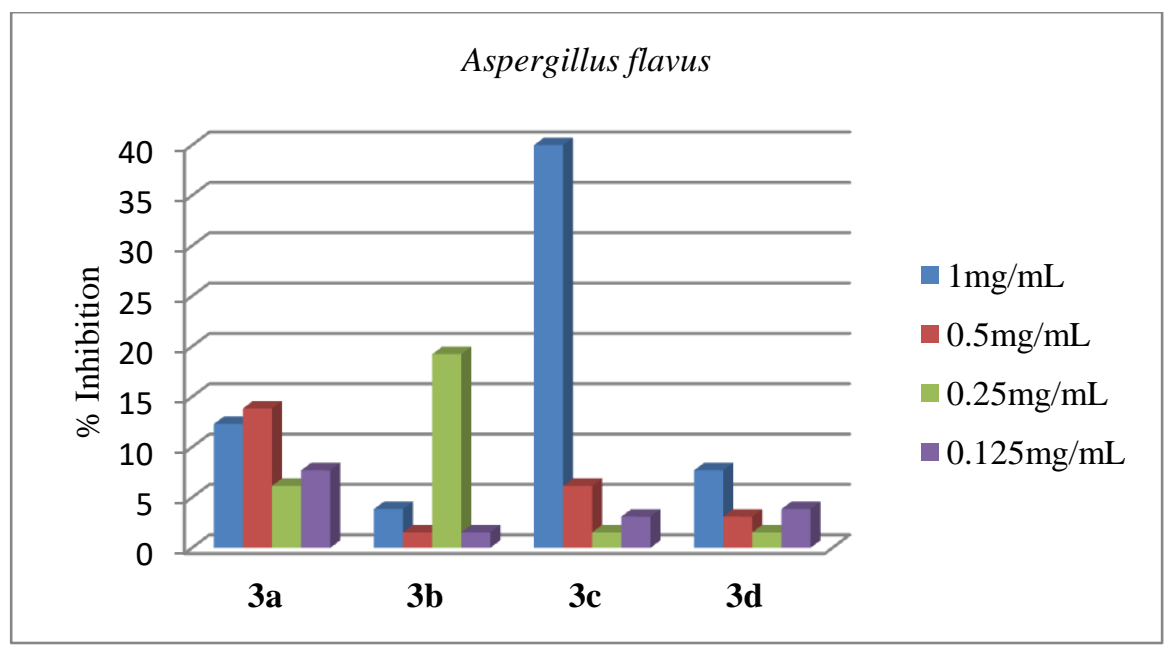

Figure 5: The triazole 3c exhibits a percentage of mycelial inhibition in the range of (40\%) against Aspergillus flavus, so it is more active on this fungus.

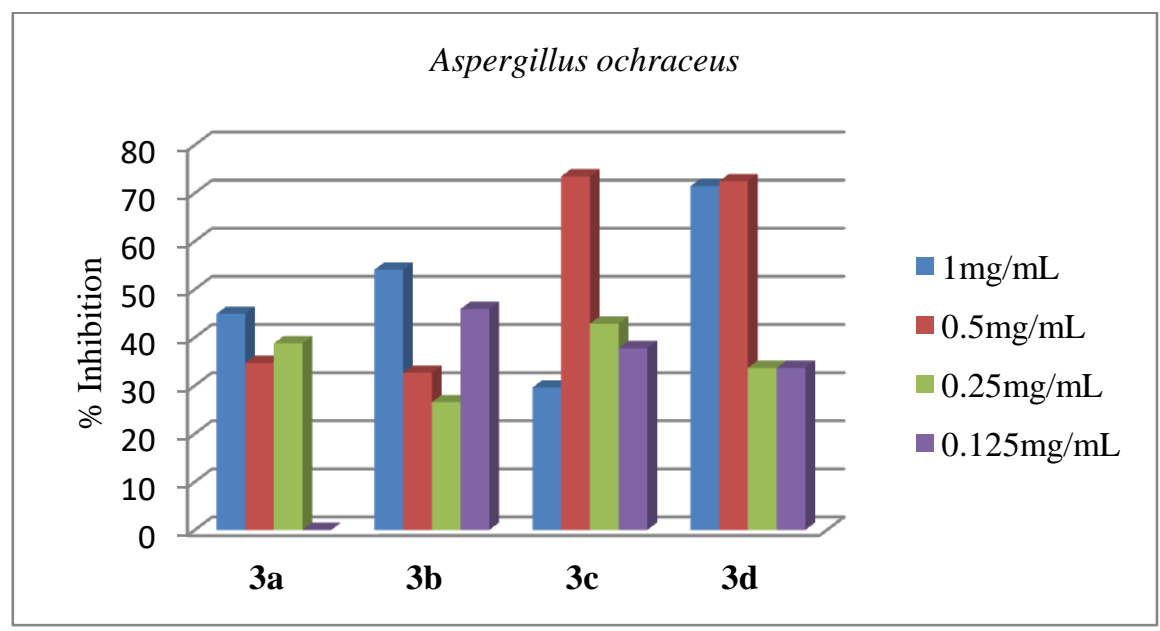

Figure 6: All triazoles show a potent antifungal effect on Aspergillus ochraceus, the best inhibition percentages are presented by $\mathbf{3 c}$ and $\mathbf{3 d}$.

In vitro evaluation of the antifungal potency of triazoles 3a-d was carried out by the direct contact method which comprises contacting the triazole with the mycelial strain of each species of phytopathogenic fungi used $[11,12]$. To achieve this, the fungal suspension is deposited in center of Petri plates charged by triazole and PDA culture medium [13].

For all concentrations of triazoles used, the zones diameters of mycelial strains growth observed are measured after 7 days incubation of the plates at $25^{\circ} \mathrm{C}$ (table III and IV). The control is realized under the same conditions in the absence of triazole. The Analysis of results obtained allows to evaluate the inhibition rate of mycelial growth, or the antifungal index $(\mathrm{T} \%)$. 
Their values are calculated according to the following formula and reported in tables III and IV. Indeed, the greater this inhibition percentage, the greater an antifungal power of the triazole.

$\mathrm{T}(\%)=\left(\mathrm{I}_{0}-\mathrm{I} / \mathrm{I}_{0}\right) \times 100$

$\mathrm{T}$ : rate of inhibition of mycelia growth, or antifungal index.

$\mathrm{I}_{0}$ : mycelial growth in the absence of triazole expressed in $\mathrm{cm}$.

I: mycelial growth in the presence of triazole expressed in $\mathrm{cm}$.

In view of the results mentioned in tables III and IV, the triazoles 3a-d show an inhibitory effect on two mycelium growth, it is more remarkable against Aspergillus ochraceus. In this case, the diameters of this strain growth in the presence of triazole are low compared to that obtained with the control, which leads to the highest inhibition rates and exceeds $30 \%$ for all triazole concentrations used. This fungus responsible for the coffee bean mildew is very sensitive to the presence of the majority of triazoles, particularly to the two triazoles $\mathbf{3 c}$ and $\mathbf{3 d}$ with concentrations of $1-0.5 \mathrm{mg} / \mathrm{mL}$, this is indicated by the most important antifungal index values, that can reach about $74 \%$ (table IV, figure 6 ).

However, Aspergillus flavus; mould contaminating the wheat grain indicated a resistance to the triazole system, the zones diameter values of this strain growth in the presence of triazole are important and are similar to the control, consequently low inhibition rates are obtained, with the exception of chloro-nitro-phenyltriazole 3c, which indicates an interest antifungal index in the order of $40 \%$ by using a concentration of $1 \mathrm{mg} / \mathrm{mL}$ (table III, figure 5).

\section{Conclusion}

In this study we synthesized 1,4-disubstituted- $N$-aryl-1,2,3-triazoles from enamine derived from methyl propiolate and arylazides without the use of copper catalysis. This acetylenic derivative reacted with morpholine by stereoselective hydroamination reaction to form exclusively enamine $E$ in good yield. The isolated enamine intermediate is added to the substituted arylazides, by 1,3-dipolar cycloaddition reaction leading to 1,4disubstituted- $N$-aryl-1,2,3-triazoles in a completely regioselective manner.

In vitro antimicrobial activity of obtained triazoles was evaluated. The testing performed by the disk diffusion revealed that the variously substituted triazoles 3a-d exhibited an inhibitory effect on the growth of most bacterial reference strains obtained from the American Type Culture Collection (ATCC): Staphylococcus aureus, Pseudomonas aeruginosa, Escherichia coli and Citrobacter freundii.

The direct contact method is adopted to achieve fungicidal activity tests on the growth of Aspergillus flavus and Aspergillus ochraceus. The inhibition rates obtained have shown a remarkable sensitivity of Aspergillus ochraceus to all triazoles 3a-d. This activity carried out by these triazoles 3a-d against bacterial and fungal microorganisms examined in this study, depends on the nature and the position of substituents which these heterocycles possess within their chemical structures.

Indeed, Chloro-nitro-phenyltriazole $\mathbf{3 c}$ acts effectively on the majority of pathogenic bacteria and fungi used with $M I C$ ranging from 1 to $0.125 \mathrm{mg} / \mathrm{mL}$. This triazole 3c witch have an electron-withdrawing (nitro) substituent and another electron-donating (chloro) substituent on the triazole aromatic system, is the most active as other triazoles 3a, 3b and 3d possessing a single substituent; either electron-withdrawing (nitro) or electrondonating (methyl) substituent.

\section{IV.1. Chemical part}

\section{Experimental Section}

All employed starting materials and solvents are commercial. The chemical reactions carried out were followed by analytical thin-layer chromatography using $0.20 \mathrm{~mm}$ silica gel 60 plates. They were revealed under a UVP mineralight UVGL-58 lamp and with $p$-anisaldehyde solution. The products obtained are purified by column chromatography using Merck 40-63 $\mu \mathrm{m}$ particle-sized silica gel (230-400 mesh) and eluted with diethyl ether-petroleum ether. Melting points ( $\mathrm{mp}$ ) were determined with a Büchi Melting-point B-450 apparatus and were not corrected. Chemical structure of synthesized products is identified by the usual spectroscopic methods (IR, NMR). IR spectra were detected using a JAFCO-430 Fourier Transform Infrared Spectrometer (FTIR) in chloroform solution. ${ }^{1} \mathrm{H}$ and ${ }^{13} \mathrm{C}$ NMR spectra were recorded on a Brucker AC $300 \mathrm{MHz}$ apparatus in deuterated chloroform solution. The chemical shifts $\delta$ are reported in parts per million ( ppm). These spectra were referenced internally to the residual deuterated chloroform $(\delta \mathrm{H}=7.26 \mathrm{ppm}$ and $\delta \mathrm{C}=77.0 \mathrm{ppm})$. The multiplicity of signals is indicated by the following abbreviations: s, $\mathrm{d}$, t meaning singlet, doublet, and triplet, respectively. The coupling constant $(J)$ is given in Hertz $(\mathrm{Hz})$.

The mono- and disubstituted aromatic azides $\mathbf{2 a}, \mathbf{2 b}, \mathbf{2 c}$ and $\mathbf{2 d}$ were synthesized from the corresponding anilines according to the procedure described by Noelting [7a] and improved by Ranu [7b] with good to excellent yields. 
- (E)-methyl-3-morpholinoacrylate 1<smiles>COC(=O)/C=C/N1CCOCC1</smiles>

To a solution of morpholine $(1.0 \mathrm{~g}, 0.01 \mathrm{~mol})$ in diethyl ether $(50 \mathrm{~mL})$, a solution of methyl propiolate $(0.88 \mathrm{~g}, 0.01 \mathrm{~mol})$ in diethyl ether $(15 \mathrm{~mL})$ was added dropwise with stirring. The product precipitates in the medium. Stirring is maintained for 4 hours at room temperature. After filtration and evaporation of the solvent in vacuo, a white solid is obtained.

Aspect: white solid $\quad \mathbf{m p :} 75^{\circ} \mathrm{C} \quad$ Rf: 0.76 [diethylether / petroleum ether 1/1].

IR $\left[\mathbf{C m}^{-1}\right.$ ]: $2922.80 ; 2871.93 ; 1696.58 ; 1603.84 ; 1433.24 ; 1371.14 ; 1108.67 ; 858.53 ; 772.69$.

${ }^{1} \mathbf{H}$ NMR $\left(300 \mathrm{MHz}, \mathrm{CDCl}_{3}, \delta \mathrm{ppm}\right): 7.34\left(\mathrm{~d}, 1 \mathrm{HC}^{3}, J=12.0 \mathrm{~Hz}\right) ; 4.67\left(\mathrm{~d}, 1 \mathrm{HC}^{2}, J=12.0 \mathrm{~Hz}\right) ; 3.69\left(\mathrm{t}, 4 \mathrm{HC}^{5}\right.$, $J=5.5 \mathrm{~Hz}) ; 3.65\left(\mathrm{~s}, 3 \mathrm{HC}^{6}\right) ; 3.19\left(\mathrm{t}, 4 \mathrm{HC}^{4}, J=5.5 \mathrm{~Hz}\right)$.

${ }^{13}$ C NMR (75MHz, $\left.\mathrm{CDCl}_{3}, \delta p p m\right): \mathrm{C}^{1}: 162.3 ; \mathrm{C}^{3}: 151.8 ; \mathrm{C}^{2}: 85.6 ; \mathrm{C}^{5}: 66.2 ; \mathrm{C}^{4}: 50.7 ; \mathrm{C}^{6}: 50.0$.

Triazoles 3a-d<smiles>[R]c1ccc(-n2nnc(C(C)=O)c2C)cc1[R]</smiles>

An equimolar mixture of arylazides 2a-d and enamine $\mathbf{1}$ was heated in an oil bath at $70{ }^{\circ} \mathrm{C}$ under stirring, without solvent for 24 hours. The triazole is precipitated and is purified by column chromatography.

- $\quad$ Methyl 1-(4-nitrophenyl)-1H-1,2,3-triazole-4-carboxylate 3a

$\mathrm{R}=p \mathrm{NO}_{2}$ :

Aspect: yellow solid $\quad \mathbf{m p :} 257^{\circ} \mathrm{C} \quad \mathbf{R f}$ : 0.56 [diethyl ether/petroleum ether 10/1].

IR[C $\mathbf{C m}^{-1}$ ]: $3076.18 ; 3056.32 ; 1719.60 ; 1584.91 ; 1530.39 ; 1259.57 ; 1030.46 ; 1012.74 ; 809.42 ; 768.69 ; 743.18$.

${ }^{1}$ H NMR $\left(300 \mathrm{MHz}, \mathrm{CDCl}_{3}, \delta \mathrm{ppm}\right): 8.96\left(\mathrm{~s}, 1 \mathrm{HC}^{5}\right) ; 8.50(\mathrm{~d}, 2 \mathrm{HAr}, J=8.8 \mathrm{~Hz}) ; 8.07$ (d, 2HAr, $\left.J=8.8 \mathrm{~Hz}\right) ; 4.07(\mathrm{~s}$, $\left.3 \mathrm{HC}^{7}\right)$.

${ }^{13}$ C NMR (75MHz, $\left.\mathrm{CDCl}_{3}, \delta \mathrm{ppm}\right): \mathrm{C}^{6}: 162.3 ; \mathrm{C}\left(\mathrm{Ar}, \mathrm{C}^{4}, \mathrm{C}^{5}\right): 160.7 ; 148.5 ; 140.2 ; 126.1 ; 125.1(2 \mathrm{C}) ; 121.8(2 \mathrm{C})$; $\mathrm{C}^{7}: 53.5$.

- methyl 1-(3-nitrophenyl)-1H-1,2,3-triazole-4-carboxylate 3b

$\mathrm{R}=m \mathrm{NO}_{2}$ :

Aspect: wight solid $\quad \mathbf{m p}: 200^{\circ} \mathrm{C} \quad$ Rf: 0.48 [diethyl ether/petroleum ether 10/1].

IR $\left[\mathbf{C m}^{-1}\right]: 2942.58 ; 2920.11 ; 1698.14 ; 1627.82 ; 1424.90 ; 1262.98 ; 1172.62 ; 1151.78 ; 1109.80 ; 1071.20 ;$ $1035.95 ; 1016.75 ; 817.04 ; 773.19 ; 729.20 ; 620.34$.

${ }^{1} \mathbf{H}$ NMR $\left(300 \mathrm{MHz}, \mathrm{CDCl}_{3}, \delta \mathrm{ppm}\right): 8.88\left(\mathrm{~s}, 1 \mathrm{HC}^{5}\right) ; 8.45$ (d, 1HAr, J=8.5Hz); 8.20 (s, 1HAr); 8.00 (t, $1 \mathrm{HAr}$, $J=8.5 \mathrm{~Hz}) ; 7.70(\mathrm{~d}, 1 \mathrm{HAr}, J=8.5 \mathrm{~Hz}) ; 4.00\left(\mathrm{~s}, 3 \mathrm{HC}^{7}\right)$.

${ }^{13} \mathrm{C}$ NMR $\left(75 \mathrm{MHz}, \mathrm{CDCl}_{3}, \delta \mathrm{ppm}\right): \mathrm{C}^{6}: 164.0 ; \mathrm{C}\left(\mathrm{Ar}, \mathrm{C}^{4}, \mathrm{C}^{5}\right): 160.5 ; 146.0 ; 137.2 ; 130.0 ; 129.6$ (2C); 124.0; 123.1; $\mathrm{C}^{7}: 52.9$.

- methyl 1-(4-chloro-2-nitrophenyl)-1H-1,2,3-triazole-4-carboxylate 3c

$\mathrm{R}, \mathrm{R}^{\prime}=\mathbf{2}-\mathrm{Cl}, \mathbf{4}-\mathrm{NO}_{2}$ :

Aspect: red brick solid $\quad \mathbf{m p}: 148^{\circ} \mathrm{C} \quad$ Rf: 0.18 [diethyl ether/petroleum ether 10/1].

IR[C $\mathbf{C m}^{-1}$ ]: $3121.35 ; 1729.71 ; 1597.21 ; 1371.99 ; 1287.84 ; 1258.94 ; 1184.27 ; 1037.05 ; 992.82 ; 893.24 ; 776.02 ;$ $740.35 ; 669.04 ; 653.92 ; 521.31 ; 432.27$.

${ }^{1}$ H NMR $\left(300 \mathrm{MHz}, \mathrm{CDCl}_{3}, \delta \mathrm{ppm}\right): 8.70\left(\mathrm{~s}, 1 \mathrm{HC}^{5}\right) ; 8.37$ (s, 1HAr); 8.08 (d, 1HAr, J= 8.7Hz); $7.80(\mathrm{~d}, 1 \mathrm{HAr}$, $J=8.7 \mathrm{~Hz}) ; 4.22\left(\mathrm{~s}, 3 \mathrm{HC}^{7}\right)$.

${ }^{13} \mathbf{C N M R}\left(75 \mathrm{MHz}, \mathrm{CDCl}_{3}, \delta \mathrm{ppm}\right): \mathrm{C}^{6}: 162.0 ; \mathrm{C}\left(\mathrm{Ar}, \mathrm{C}^{4}, \mathrm{C}^{5}\right): 160.0 ; 149.0 ; 140.3 ; 137.0 ; 133.5 ; 126.6 ; 122.5 ; 119.0 ; \quad \mathrm{C}^{7}$ : 51.7.

- methyl 1-p-tolyl-1H-1,2,3-triazole-4-carboxylate 3d

$\mathbf{R}=p \mathrm{CH}_{3}$ :

Aspect: yellow solid $\quad \mathbf{m p}: 76^{\circ} \mathrm{C} \quad$ Rf: 0.42 [diethyl ether/petroleum ether $\left.10 / 1\right]$. 
IR $\left[\mathbf{C m}^{-1}\right]: 3143.41 ; 2956.96 ; 1713.88 ; 1524.86 ; 1342.43 ; 1266.07 ; 1177.13 ; 1108.51 ; 1038.77 ; 866.36 ; 854.86$; 771.44; 749.05; 684.09; 527.41.

${ }^{1} \mathbf{H}$ NMR $\left(300 \mathrm{MHz}, \mathrm{CDCl}_{3}, \delta \mathrm{ppm}\right): 8.02\left(\mathrm{~s}, 1 \mathrm{HC}^{5}\right) ; 8.10(\mathrm{~d}, 2 \mathrm{HAr}, J=7.8 \mathrm{~Hz}) ; 8.27$ (d, 2HAr, J=7.8Hz); 4.12 (s, $\left.3 \mathrm{HC}^{7}\right), 3.23\left(\mathrm{~s}, 3 \mathrm{H}\left(\mathrm{CH}_{3}\right)\right.$.

${ }^{13}$ C NMR (75MHz, $\left.\mathrm{CDCl}_{3}, \delta \mathrm{ppm}\right): \mathrm{C}^{6}: 159.3 ; \mathrm{C}\left(\mathrm{Ar}, \mathrm{C}^{4}, \mathrm{C}^{5}\right): 151.6 ; 140.1 ; 138.2 ; 124.1 ; 122.1(2 \mathrm{C}) ; 119.4(2 \mathrm{C})$; $\mathrm{C}^{7}: 50.5 ; \mathrm{C}\left(\mathrm{CH}_{3}\right): 21.4$.

\section{IV.2. Biological part}

All the reference strains of bacteria used in this study are become from Pasteur Institute of Algeria. They are listed in table V.

Table V: Bacteria used

\begin{tabular}{cccc}
\hline Strains & Codes & Provenance & Types \\
\hline Staphylococcus aureus $(\mathrm{Sa})$ & ATCC25923 & & Gram- \\
Pseudomonas aeruginosa $(\mathrm{Pa})$ & ATCC27853 & Institute Pasteur & \\
Escherichia coli $(\mathrm{Ec})$ & ATCC25922 & Algers-Algeria & Gram+ \\
Citrobacter freundii $(\mathrm{Cf})$ & ATCC8090 & & \\
\hline
\end{tabular}

In tubes containing $10 \mathrm{~mL}$ of sterile physiological water $(0.9 \% \mathrm{NaCl})$ is emulsified a few colonies of a pure culture of each bacteria strain. The inoculums obtained are adjusted to the turbidity of a $0.5 \mathrm{McFarland}$ standard. Petri plates containing the Mueller Hinton-agar are charged of inoculum, using a dry and sterile swab. Seeding is effected three times into agar surface; the swab is then passed round the edge of the agar surface [10]. Allow the plate to dry at ambient temperature. Disks are then deposited on the surface of Petri plates using a sterile forceps. The disks used are round blotting paper with a diameter of $5 \mathrm{~mm}$ and a thickness of $0.4 \mathrm{~mm}$. They are sterilized before each use. They are filled with $20 \mu \mathrm{l}$ of a solution containing the triazole dissolved in DMSO.

Finally, Petri plates with lid closed are incubated in an oven at $37{ }^{\circ} \mathrm{C}$ for 24 hours before measuring the inhibition zones diameter of the bacterial growth in millimeters (D: $\mathrm{mm}$ ).

The different concentrations $(0.5 ; 0.25 ; 0.125 \mathrm{mg} / \mathrm{mL})$ are obtained by dilutions in DMSO of the stock standard solution $(1 \mathrm{mg} / \mathrm{mL})$ which consists of each of triazoles 3a-d dissolved in DMSO.

Moreover, two fungi use: Aspergillus ochraceus and Aspergillus flavus are isolated from moulds colonized respectively coffee and wheat grains and placed in a PDA agar medium [11]. These mycetes are identified in the microbiology laboratory of Tahri Mohamed-Bechar University-Algeria, based on several morphological, macroscopic and microscopic identification criteria [12]. The cultures for the two fungal species were maintained on PDA medium in inclined tube (incubation at $30^{\circ} \mathrm{C}$ to the proper sporulation). The spores are recovered and added with stirring to a mixture of tween $80(3 \mathrm{~mL}, 0.1 \%)$ and agar $(4.5 \mathrm{~mL}, 0.2 \%)$.

$(1 \mathrm{~mL})$ of each triazole concentration is added in test tubes containing PDA $(19 \mathrm{~mL})$, which stirring with a vortex. The obtained mixtures are streaked on the surface of the Petri plates previously sterilized. After solidification, a drop of the spore suspension containing approximately $10^{6} \mathrm{CFU} / \mathrm{mL}$ of each of two fungal strains is deposited in center of the Petri plate containing a mixture of culture medium PDA and triazole [13].

The Petri plates are incubated for 7 days at $25^{\circ} \mathrm{C}$. A Petri plates considered as a control is prepared as previously but in the absence of triazole. The antifungal activity was determined by measuring the zones diameter of the mycelial growth $(\mathrm{I}: \mathrm{cm})$ in the presence of triazole at different concentrations, while $\left(\mathrm{I}_{0}: \mathrm{cm}\right)$ designates the diameter value of mycelial growth without triazole. This makes it possible to calculate the antifungal index or the inhibition rate by the following relationship [13]:

$\mathrm{T}(\%)=\left(\mathrm{I}_{0}-\mathrm{I} / \mathrm{I}_{0}\right) \times 100$.

Each test was repeated three times for all triazole concentrations used.

\section{References}

[1]. a) Colanceska-Ragenovic, K.; Dimova, V.; Kakurinov, V.; Molnar, D.-G.; Buzarovska, A. Molecules 6, 815-824, 2001; b) Canoa, P.; Gonzalez-Moa, M. J.; Pannecouque, C.; Teijeira, M.; DeClercq, E.; Teran, C.; Uriarte, E. Chemical \& Pharmaceutical BulletinChem. Pharm. Bull. Tokyo 54, 10, 1418-1420, 2006; c) Kamel, A.; Shankaraiah, N.; Devaiah, V.; Reddy, L.; Juvakar, A.; Sen, S.; Kurian, N.; Zingde, S. Bioorganic \& Medicinal Chemistry Letters 18, 1468-1473, 2008; d) Gallardo, H.; Conte, G.; Bryk, F.; Lourenço, M.C.S.; Ferreira, V.F.; Costa, M.S. J. Braz. Chem. Soc. 18, 6, 1285-1291, 2007; e) Pai, M.P.; Jones, A. L. Antimicrob. Agents Chemother 48, 11, 4441-4443, 2004; f) Müllenborn, C.; Steiner, U.; Ludwig, M.; Oerke, E.-C. European Journal of Plant Pathologie 120, 2, 157-166, 2008; g) Kim, D-K.; Kim, J.; Park, H.-J. Bioorganic \& Medicinal Chemitry Letters 14, 2401-2405, 2004. 
[2]. a) Wu, P.; Feldman, A. K.; Nugent, A. K.; Hawker, C. J.; Scheel, A.; Voit, B.; Pyun, J.; Frechet, J.-M. J.; Sharpless, K. B.; Fokin, V. V. Angew. Chem. Int. Ed. 43, 3928-3932, 2004; b) Diaz, D. D.; Punna, S.; Holzer, P.; McPherson, A. K.; Sharpless, K. B.; Fokin, V.V.; Finn, M. G. J. Polym. Sci. Part A: Polymer Chemistry 42, 4392-4403, 2004.

[3]. a) Meldal, M.; Tornøe, C.W. Chem. Rev. 108, 2952-3015, 2008; b) Romeiro, G. A.; Pereira, L.O.R.; De-Souza, M. C. B. V.; Ferreira, V.F.; Cunha, A.C. Tetrahedron letters 38, 29, 5103-5106, 1997.

[4]. Tanaka, Y.; Oda, S.; Ito, S.; Kakehi, A. Heterocycles 65, 2, 279-285, 2005.

[5]. a) Bastide, J.; Elghandour, N.; Henry-Rousseau, O. Tetrahedron Letters 13, 41,4225-4228, 1972; b) Bast, K.; Christ, M.; Huisgen, R.; Sustman, R. Chem. Ber.106, 3275-3279, 1973.

[6]. a) MCMullen, C. H.; Stirling, C. J.M. J. Chem. Soc. (B).1217-1220, 1966; b) Hickmott, P. W. Tetrahedron 38, 14, 1975-2050, 1982; c) LeBlanc, M.; Santini, G.; Riess, J. G. Tetrahedron Letters 16, 47, 4151-4152, 1975; d) Le Blanc, M.; Santini, G.; Gallucci, J.; Riess, J. G. Tetrahedron 33, 12, 1453-1456, 1977; e) Pohlki, F.; Doye, S. Chem. Soc. Rev. 32, 104-114, 2003, f) Müller, T. E.; Beller, M. Chem. Rev. 98, 675-703, 1998.

[7]. a) Noelting, E.; Michel, O. Bull. Ber. 26, 86, 1893; b) Ranu, B. C.; Sarkar, A.; Chakraborty, R. J. Org. Chem. 59, 15, 4114-4116, 1994.

[8]. Grimes, K. D.; Gupte, A.; Aldrich, C. C. Synthesis 9, 1441-1448, 2010.

[9]. a) Texier, F.; Derdour, A.; Benhaoua, H.; Benabdellah, T.; Yebdri, O. Tetrahedron Letters 23, 18, 1893-1896, 1982; b) Palacios, F.; Maochoa de Retana, A.; Pagalday, J. Heterocycles 40, 2, 543-537, 1995.

[10]. a) Rahal, K. Standardisation de l'Antibiogramme à l'Echelle Nationale (Médecine Humaine et Vétérinaire, $6^{\mathrm{ème}}$ édition 2011; b) Nejjah, F.; Ouhssine, M.; Srhiri, A-A.; El yachioui, M.; Hajjaji, N. Bull. Soc. Pharm. Bordeaux 145, 85-90, 2006; c) Bolou, G.E.K.; Attioua, B.; N'guessan, AC.; Oulibaly, A.; N'guessan, J.D.; Djaman, A. J. Bulletin de la Société Royale des Sciences de Liège 80, 772-790, 2011; d) Ntumba, J. K.; Taba, K.M.; Robiette, R. Chimie Nouvelle, 117, 2014; e) Benine, M.L.; Azzi, I.; Larbi Daouadji, K.; Kanoun, K.; Abbouni, B. European Scientific Journal 11, 21, 1857-7881, 2015; f) Bassole, H. N.; Kabore, Z.; Traore, A.S. Pharm. Méd. Trad. Afri. 11,113-122, 2001; g) Ansari, K.F.; Lal, C.; Khitoliya, R. K. J. Serb. Chem. Soc.76, 3, 341-352, 2011; h)Valgas, C.; Machado de Souza, S.; Smânia, E.F.A.; Smânia Jr., A. Brazilian Journal of Microbiology 38, 369-380, 2007, i) Jawad, A.; K Shneine, J.; Ahmed, A.; M Abdulrasool, M. International Journal of Research in Pharmacy and Chemistry 2, 4, 11091123, 2012; j) Prasun, C.; Wakode, S. R. International Journal of Science and Research (IJSR) 4, 1, 2319-7064, 2015; k) Zaranappa;Vagdevi, H M.; Jayanna, N D.; Latha. K P. Der Pharma Chemica 4, 4, 1754-1758, 2012; 1) Agrawal, R.; Pancholi, S. S. Der Pharma Chemica 3, 6, 32-40, 2011.

[11]. a) Perrone, G.; Susca, A.; Cozzi, G.; Ehrlich, K.; Varga, J.; Frisvad, J.C.; Meijer, M.; Noonim, P.; Mahakarnchanakul, W.; Samson, R.A. Studies in Mycology 59, 53-66, 2007; b) Pitt, J. I.; Hocking, A. D.; Bhudhasamai, K.; Miscamble, B. F.; Wheeler, K. A.; Tanboon, E.K.P. International Journal of Food Microbiology 23, 35-53, 1994; c) Nguyen, M-T.; Tozlovanu, M.;Tran, T-L.; PfohlLeszkowicz, A. Food Chemistry 105, 42-44, 2007.

[12]. a) Djossou, O.; Perraud-Gaime, I.; Lakhal-Mirleau, F.; Rodriguez-Serrano, G.; Karou, A.G.T.; Niamke, S.; Ouzari, I.; Boudabous, A.; Roussos, S. Anaerobe 30, 1-6, 2011; b) Botton, B.; Breton, A.; Fèvre, M.; Gauthier, S. ; Guy, P.; Larpent, J.P.; Reymond, P.; Sanglier, J. J.;Vayssier, Y.; Veau, P. Moisissures utiles et nuisibles, Importance industrielle, Ed. Masson, Paris, 512, 1990; c) Samson, R.A.; Noonim, P.; Meijer, M.; Houbraken, J.; Frisvad, J.C.; Varga, J. Study Mycology 59, 129-145, 2007; d) Rodrigues, P.; Soares, C.; Kozakiewicz, Z.; Paterson, R.R.M.; Lima, N.; Venâncio, A. Communicating Current Research and Educational Topics and Trends in Applied Microbiology, A. Méndez-Vilas (Ed), 2, 527-534, 2007; e) Labiod, R.; Aouadi, S.; Bouhaddouda, N. International Journal of Pharmacy and Pharmaceutical Sciences 7, 7, 208-211, 2015.

[13]. a) Salhi, N.; Goumni, Z.; Salhi, A.; Mehani, M.; Terzi V. Revue El Wahat pour les Recherches et les Etudes 8, 2, 34-44, 2015; b) Kanoun, K.; Abbouni, B.; Bénine, M-L.; Benmahdi, F-Z.; Marouf, B. European Scientific Journal 10, 12, 2014; c) Bougandoura, N.; Bendimerad, N.; Revue des BioRessources 2, 1, 1-7, 2012; d) Ismaili, R.; Lamiri, A.; Moustaid, K. International Journal of Innovation and Scientific Research 12, 2, 499-505, 2014; e) Oubair, A.; Fihi, R.; Mazouz, H. Bulletin de la Société Royale des Sciences de Liège 85, 119-129, 2016. 